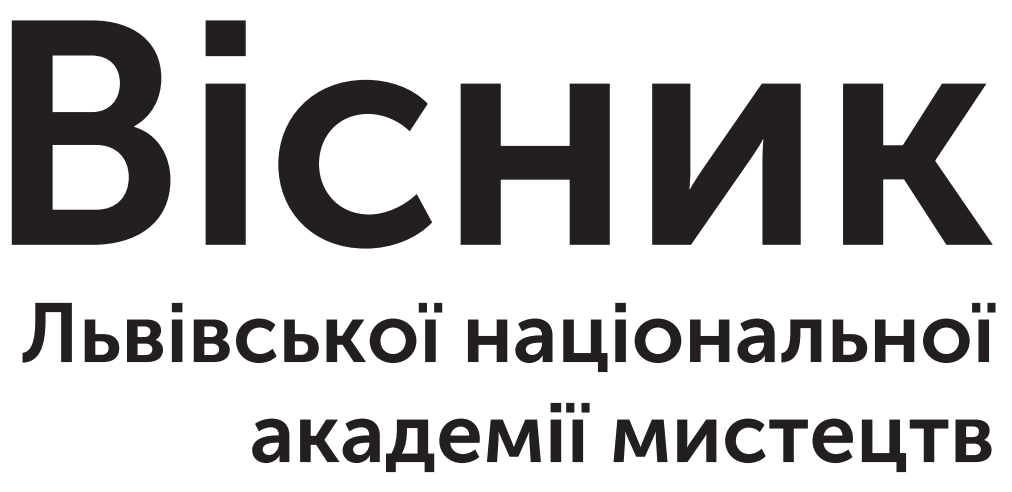

\title{
Bulletin of Lviv National \\ Academy of Arts
}

Ars longa vita brevis

\section{Випуск}

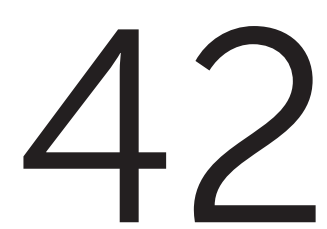

Видається з 1990 р. 
ББК Щ. я 54 (4 УКР-2Л6В)

УДК 7(477.83-25)

Черговий випуск «Вісника Львівської національної академії мистецтв» складається 3 таких розділів: «Проблеми теорії мистецтва та художня освіта», «Дизайн», «Мистецтвознавчий пошук», «Мистецтво у міждисциплінарних дослідженнях». Розглядаються проблеми і завдання образотворчого, декоративно-прикладного мистецтва та дизайну, реставрації творів мистецтва, мистецької освіти, критики і соціокультурної діяльності.

3бірник адресований науковцям, студентам, викладачам середніх професійних і вищих навчальних закладів, аспірантам, докторантам, діячам культури і мистецтва.

The next issue of «BULLETIN» contains the traditional sectionse «Theory of art», «Design», «Artsearching», «Cultural figures». The problems of fine and applied arts, design, restoration of pieces of art, art education, art criticism, social and cultural activities have been considered.

Scientific publication is addressed for researchers, students, teachers, specalized and higher educational institutions, $\mathrm{PhD}$ and doctoral students, professinals of cultural and art sphere.

Редакційна колегія:

Володимир Одрехівський

$(20108 a)$

Андрій Бокотей

Роман Яців

(заступник голови)

Орест Голубець

Оксана Маланчук-Рибак

Костянтин Нікітенко

Андрій Пучков

Галина Стельмащук

Роксолана Патик

Ростислав Шмагало ректор ЛНАМ, народний художник України, професор, кандидат мистецтвознавства;

професор кафедри художнього скла ЛНАМ, академік НАМУ, керівник ЗРНМЦ НАМУ, народний художник України, Лауреат Національної премії ім. Т. Шевченка;

проректор з наукової роботи ЛНАМ, кандидат мистецтвознавства, професор кафедри історії і теорії мистецтва;

доктор мистецтвознавства, професор, завідувач кафедри художньої кераміки ЛНАМ, член-кореспондент НАМУ;

доктор історичних наук, професор кафедри історії і теорії мистецтва ЛНАМ;

доктор історичних наук, завідувач кафедри менеджменту мистецтва ЛНАМ, доцент;

доктор мистецтвознавства, професор кафедри дизайну Інституту мистецтв Київського університету імені Бориса Грінченка, лауреат Державної премії України в галузі архітектури, заслужений діяч мистецтв України;

доктор мистецтвознавства, професор, завідувач кафедри історії і теорії мистецтва ЛНАМ; академік НАМУ;

перший проректор ЛНАМ, кандидат мистецтвознавства, професор кафедри менеджменту мистецтва, учений секретар ЗРНМЦ НАМУ;

доктор мистецтвознавства, професор кафедри історії і теорії мистецтва ЛНАМ, декан факультету історії і теорії мистецтва; 
Олег Боднар доктор мистецтвознавства, професор кафедри

дизайну та основ архітектури Інституту архітектури

Національного університету «Львівська політехніка»;

Тетяна Кротова доктор мистецтвознавства, професор кафедри художнього моделювання костюма Київського національного університету технологій та дизайну;

Владислав Грешлик кандидат мистецтвознавства, завідувач кафедри художньої освіти та мистецтва, доцент Пряшівського Університету у Пряшеві (Словаччина);

Вальдемар Делюга доктор наук (prof. dr hab), професор Університету в Остраві (Чехія);

Олена Никорак доктор мистецтвознавства, професор, провідний науковий співробітник Інституту народознавства НАН України;

Євгеній Сахута доктор мистецтвознавства, професор, провідний науковий співробітник відділу образотворчого і декоративно-прикладного мистецтва Державної наукової установи «IMЕФ ім К. Крапиви НАН Білорусі» (Білорусь);

Уршула Слюсарчик доктор наук (prof. dr hab), професор, заступник директора з науково-творчої роботи Інституту образотворчого мистецтва Університету ім. Яна Кохановського в м. Кельце (Польща);

Рорі Фіннін доктор наук (prof. dr hab), директор Центру українських студій Кембриджського університету (Великобританія);

Наталія Левкович доктор мистецтвознавства, доцент кафедри історії і теорії мистецтва ЛНАМ;

Наталія Бенях кандидат мистецтвознавства, ст. викладач кафедри художнього (відповідальний секретар) дерева, провідний фахівець з видавничої діяльності ЛНАМ.

Вісник ЛНАМ включений до переліку наукових фахових видань України, у яких можуть публікуватися результати дисертаційних робіт на здобуття наукових ступенів доктора і кандидата наук. Затверджено наказом Міністерства освіти і науки України від 21.12.2015 № 1328

Друкується за ухвалою Вченої ради Львівської національної академії мистецтв від 26.12.2019р. протокол №4

ISSN 2524-0943 (Print)

ISSN 2663-886X (Online)

Key title: Visnik L'vivs'koi nacional'noi akademii mistectv

Abbreviated key title: Visn. L'vìv. nac. akad. mistec.

(c) ЛНАМ, 2019 


\section{M I C T}

\section{ПРОБЛЕМИ ПЛАСТИЧНОГО ТА УЖИТКОВОГО МИСТЕЦТВА}

Наталія Левкович

Осередок єврейського мереживоплетіння в Сасові другої половини XIX - першої третини XX ст.

Ольга Ямборко

Українське промислове килимарство 1940-1980-х рр. у системі «народних художніх промислів»: між

народним мистецтвом, художньою якістю та економічною доцільністю

Nataliya Benyakh

Challenges and prospects for the world studio glass development: based on the results of the International Scientific and Practical Conference-presentation "World Studio Glass. Tradition and Experiment"

Іван Франк. Ірина Щерба

Стилістика ар-деко в архітектурній металопластиці Львова кінця XIX ст.

Олексій Кожеков

Технічна різноманітність вітража та його естетичне навантаження

\section{дИзАЙн}

Євген Гула. Алла Осадча. Олеся Пільгук

Вплив ландшафту на стиль у дизайні

Оксана Мельник. Іван Селіванов

Інфографіка як засіб візуальної інтерпретації астрономічних понять у вебдизайні

\section{МИСТЕЦЬКІ ПОСТАТІ}

Руслана Шеретюк

Духовне майбутнє людства через призму мистецького доробку сучасної української художниці

Оксани Мась

Світлана Лупій

Володимир Черкасов: митець, педагог

Ярослав Кравченко

Художник-неовізантист Петро Холодний-старший: штрихи до портрету 


\section{МИСТЕЦТВОЗНАВЧИЙ ПОШУК}

\section{Уляна Щевйова}

Художні розписи у програмі оздоблення вхідних просторів житлових споруд Східної Галичини кінця XIX - першої третини XX ст.

Юлія Каменецька

Мистецтво портрета в сучасному українському екслібрисі

\section{МИСТЕЦТВО У МІЖДИСЦИПЛІНАРНИХ ДОСЛІДЖЕННЯХ}

Анатолій Войнаровський

Реформа сфери інтелектуальної власності в Україні

Інна Шворак

Гендерні субкультури у весільній традиції Західної Волині як соціально-міфологічна структура 


\title{
НАУКОВЕ ВИДАННЯ
}

\author{
Вісник Львівської національної академії мистецтв \\ Вип. 42. - Львів : ЛНАМ, 2019. - 109 с. : іл. \\ ISSN 2524 - 0943 \\ Key title: Visnik L'viv. nac. akad. mistec. \\ ISSN 2663 - 886X (Online)
}

\author{
Літературна редакція Ірина Костюк \\ Технічна редакція і, \\ комп'ютерна верстка \\ Ярина Турчиняк \\ Дизайн \\ Петро Нагірний
}

Редакція залишає за собою право редагувати та скорочувати матеріали.

Відповідальність за достовірність інформації несе автор.

Думка редакції може не збігатися з думкою автора.

При використанні наших публікацій посилання на

«ВісникЛьвівської національної академії мистецтв» обов'язкове

Підписано до друку 26 грудня 2019 р.

Формат 84х108/32. Гарнітура Academia.

Папір офсетний №1. Друк офсетний.

Умовн. друк. арк. 19.06. Наклад 100 прим.

Свідоцтво про внесення до Державного реєстру видавців

ДК № 4745 від 14 липня 2014 р.

Відділ Видавництва та інформації ЛНАМ

вул. Кубійовича, 35Б, м. Львів, 79011

тел. (032) 253-35-12; факс: (032) 276-14-82

www.lnam.edu.ua

https://visnyk.Inam.edu.ua/uk

visnyk@Inam.edu.ua

Друк ТзОВ «Простір-М»

Свідоцтво ДК № 2167 від 21.04.2005 р.

79000, м. Львів, вул. Чайковського, 8

Тел.: (032) 261-09-05, e-mail: prostir.druk@gmail.com 